\title{
Increased glucose turnover and glucose cycling in acromegalic patients with normal glucose tolerance
}

\author{
S. Karlander ${ }^{1}$, M. Vranic ${ }^{2}$ and S. Efendić ${ }^{1}$ \\ ${ }^{1}$ Department of Endocrinology, Karolinska Hospital, Stockholm, Sweden and \\ ${ }^{2}$ Department of Physiology, University of Toronto, Toronto, Canada
}

\begin{abstract}
Summary. To characterize the diabetogenic effects of growth hormone, we simultaneously measured glucose turnover with $2-{ }^{3} \mathrm{H}$ - and $6-{ }^{3} \mathrm{H}$-glucose in six acromegalic patients with normal fasting blood glucose and oral glucose tolerance tests. Eight healthy volunteers served as controls. All subjects were studied under both basal conditions and during glucose infusion $\left(2 \mathrm{mg} \cdot \mathrm{kg}^{-1} \cdot \mathrm{min}^{-1}\right)$. We determined true glucose production and irreversible glucose uptake using $6{ }^{3} \mathrm{H}$-glucose and glucose cycling (difference between $2-{ }^{3} \mathrm{H}-$ and $6-{ }^{3} \mathrm{H}$-glucose). After an overnight fast, glucose production was higher than normal in the acromegalic patients $(2.18 \pm 0.15$ vs $1.85 \pm$ $\left.0.03 \mathrm{mg} \cdot \mathrm{kg}^{-1} \cdot \min ^{-1}, \quad p<0.05\right)$ despite hyperinsulinaemia. The metabolic clearance rate was normal. During the glucose infusion, glucose production was not suppressed as effectively in the acromegalic patients as in controls nor was glucose up-
\end{abstract}

take augmented, while metabolic clearance rate was decreased. In acromegaly, basal glucose cycling was increased $\left(0.44 \pm 0.08\right.$ vs $\left.0.25 \pm 0.07 \mathrm{mg} \cdot \mathrm{kg}^{-1} \cdot \mathrm{min}^{-1}, p<0.05\right)$. Furthermore cycling of endogenous glucose measured during glucose infusion was also augmented $(0.41 \pm 0.05$ vs $0.24 \pm 0.05 \mathrm{mg}$. $\mathrm{kg}^{-1} \cdot \min ^{-1}, p<0.05$ ). Hence the increase of glucose cycling (70\%) was much more pronounced than that of glucose production $(17 \%)$. In conclusion, small defects in glucose metabolism in acromegaly can be detected with sensitive tracer methods. These derangements are confined to the liver under fasting conditions, but are of both hepatic and extrahepatic origin during glucose loading.

Key words: Acromegaly, glucose turnover, glucose cycle.

tolerance. For comparison, a group of healthy subjects and a patient with acromegaly and newly diagnosed diabetes mellitus were also included. Total glucose production and total glucose phosphorylation were determined with $2-{ }^{3} \mathrm{H}$-glucose while true glucose production and irreversible glucose uptake were measured with ${ }^{6}{ }^{3} \mathrm{H}$-glucose. The difference in glucose production calculated using these two tracers gives a measure of glucose cycling (GC). This metabolic pathway is the main futile cycle operating in the liver. GC involves phosphorylation of glucose to glucose 6-phosphate by glucokinase and its dephosphorylation by glucose 6-phosphatase.

\section{Subjects and methods}

\begin{abstract}
Subjects
Seven patients with acromegaly (Table 1 ) and eight healthy control subjects were studied. All patients were evaluated for severity of acromegaly at the Department of Endocrinology, Karolinska Hospital. The disease was newly diagnosed in six patients, while one patient (KOR) had significant symptomatology despite earlier transsphenoidal pituitary surgery and external irradiation. The diagnosis was based on clinical findings as well as on sustained elevation of plasma GH levels and on altered GH responses to L-DOPA [10] and thyrotropin-releasing hormone [11]. An acidophilic or basophilic pituitary
\end{abstract}


Table 1. Clinical and metabolic data on the acromegalic patients

\begin{tabular}{|c|c|c|c|c|c|c|c|}
\hline \multirow[t]{2}{*}{ Patient } & \multirow[t]{2}{*}{ Sex } & \multirow{2}{*}{$\begin{array}{l}\text { Age } \\
\text { (years) }\end{array}$} & \multirow{2}{*}{$\begin{array}{l}\text { Body mass index } \\
\left(\mathrm{kg} / \mathrm{m}^{2}\right)\end{array}$} & \multicolumn{2}{|c|}{ Plasma glucose (OGTT) } & \multirow{2}{*}{$\begin{array}{l}\text { Basal plasma } \\
\text { growth hormone } \\
(\mu \mathrm{g} / 1)\end{array}$} & \multirow{2}{*}{$\begin{array}{l}\text { Basal serum } \\
\text { prolactin }^{\mathrm{a}} \\
(\mu \mathrm{g} / \mathrm{l})\end{array}$} \\
\hline & & & & \multicolumn{2}{|l|}{$(\mathrm{mg} / \mathrm{dl})$} & & \\
\hline KOR & $\mathbf{M}$ & 38 & 32.7 & 79 & 130 & 6 & 5 \\
\hline OR & $\mathbf{M}$ & 23 & 23.6 & 94 & 86 & 232 & 21 \\
\hline RK & $\mathrm{F}$ & 47 & 28.3 & 79 & 126 & 6 & 4 \\
\hline BT & $\mathbf{M}$ & 59 & 27.4 & 90 & 149 & 5 & 3 \\
\hline BA & M & 51 & 27.8 & 198 & - & 188 & 6 \\
\hline
\end{tabular}

${ }^{a}$ mean of 4-6 values for each patient

adenoma was found during transsphenoidal surgery in all patients. There was no significant hyperprolactinaemia in any patient (Table 1). Type 2 (non-insulin-dependent) diabetes mellitus was discovered in one patient (BA), while in the remaining patients fasting plasma glucose levels as well as an oral glucose tolerance test (OGTT) were normal [12]. None of the patients were taking any medication except KOR, who was receiving appropriate hormonal replacement therapy consisting of cortisone acetate, thyroxine and testosterone. With the exception of one patient (AS) who had secondary amenorrhoea of a few years duration and who regained normal menses after transsphenoidal surgery, there was no evidence of pituitary insufficiency.

The control group consisted of five male and three female healthy volunteers aged $43.8 \pm 2.3$ years (mean \pm SEM). The average body mass index was $23.0 \pm 0.8 \mathrm{~kg} / \mathrm{m}^{2}$. All subjects had normal OGTT [12] with fasting and $2 \mathrm{~h}$ glucose values being $77 \pm 1$ and $90 \pm 7 \mathrm{mg} / \mathrm{dl} \mathrm{re-}$ spectively.

\section{Infusions}

All subjects were studied in the recumbent position at 08.00 hours after a 12-14 h overnight fast. An indwelling catheter was placed in an antecubital vein in each arm, one for infusion of unlabeled and isotopically labeled glucose and the other for blood sampling.

After cannulation a primed constant infusion of sterile and nonpyrogenic $2{ }^{3} \mathrm{H}$-glucose and $6-{ }^{3} \mathrm{H}$-glucose (New England Nuclear, Boston, Mass, USA) in isotonic saline was begun and continued throughout the experiment $(240 \mathrm{~min})$. The priming dose of labeled glucose was $24-30 \mu \mathrm{Ci}\left(1 \mathrm{Ci}=3.7 \times 10^{10}\right.$ bequerels $)$ and the rate of infusion was $0.20-0.25 \mu \mathrm{Ci} / \mathrm{min}$. After an equilibration period of 120 min an infusion of unlabeled glucose was begun as well. It was given at a rate of $2 \mathrm{mg} \cdot \mathrm{kg}^{-1} \cdot \mathrm{min}^{-1}$ by means of a Tecmar pump. The concentration of glucose in the infusate was measured in each experiment with the same assay as the plasma samples.

\section{Blood sampling}

During the equilibration period blood samples were drawn at 0,90 , 100,110 and $120 \mathrm{~min}$. At the start of the infusion of unlabeled glucose, the clock was reset to zero and samples were drawn every 10 min thereafter.

\section{Analytical procedures}

Heparinized blood was kept on ice until centrifuged at $4^{\circ} \mathrm{C}$. A plasma sample was used for determination of plasma glucose in triplicate while the rest was frozen at $-20^{\circ} \mathrm{C}$ for later analysis of C-peptide, insulin, glucagon and $\mathrm{GH}$ as well as for specific activity of glucose. Plasma glucose was determined by the glucose oxidase method [13]. Cpeptide and $\mathrm{GH}$ were measured by radioimmunoassay with commercially available kits (Novo Research, Bagsvaerd, Denmark and Phadebas hGH Prist, Pharmacia, Sweden, respectively). Insulin was measured by radioimmunoassay using antibodies raised in guinea pigs against porcine insulin. Human insulin served as a standard [14]. Blood samples for analysis of glucagon were collected in prechilled tubes containing Trasylol and EDTA. The radioimmunoassay was based on the method of Faloona and Unger [15] using the 30K antibody.

\section{Tracer methods and calculations}

Measurements of specific activity of glucose were performed after deproteinization with $\mathrm{Ba}(\mathrm{OH})_{2}$ and $\mathrm{ZnSO}_{4}$. The supernatant was passed through ion-exchange chromatography to remove labeled metabolites. An aliquot of the eluate was evaporated to dryness under reduced pressure at $40^{\circ} \mathrm{C}$. After addition of water and liquid scintillation solution the total radioactivity from $2-{ }^{3} \mathrm{H}$-glucose and $6-{ }^{3} \mathrm{H}$-glucose was measured in a beta scintillation counter. An external standard was used for quenching. All samples and standards were counted for $50 \mathrm{~min}$ and the counts for the samples were at least 4 times higher than for the background.

The radioactivity of $6-{ }^{3} \mathrm{H}$-glucose was determined as described by Dunn et al. [16]. In short, $10.0 \mathrm{mg}$ of glucose was added as a carrier to $2 \mathrm{ml}$ of the eluate from ion-exchange chromatography. Glucose was then oxidized with periodate to 5 molecules of formic acid (derived from carbons 1-5) and 1 molecule of formaldehyde, derived from carbon 6 . After addition of dimedon, formaldehyde precipitates as formaldemethone. The radioactivity of the precipitate was determined after filtering, drying and weighing.

The radioactivity of $2-{ }^{3} \mathrm{H}$-glucose was calculated as the difference between total radioactivity and that of $6{ }^{3} \mathrm{H}$-glucose as measured with the dimedon procedure. Aliquots of the infused mixture of $2{ }^{3} \mathrm{H}-\mathrm{glu}$ cose and $6{ }^{3} \mathrm{H}$-glucose were run along with the plasma samples to determine the exact rate of the tracer infusion and to estimate possible losses of $6{ }^{3} \mathrm{H}$-glucose relative to $2-{ }^{3} \mathrm{H}$-glucose during the dimedon procedure. On average, $6-{ }^{3} \mathrm{H}$-glucose accounted for $50 \%$ of total radioactivity in the infusate in acromegalics and controls. Aliquots of $2-{ }^{3} \mathrm{H}$-glucose did not display any radioactivity above background after being passed through the dimedon procedure.

The rates of glucose production ( $\mathrm{Ra}$, rate of appearance) and of glucose uptake ( $\mathrm{Rd}$, rate of disappearance) were determined using the method of primed constant tracer infusion [17]. This method is based on modified single compartment analysis of glucose turnover, in which it is assumed that rapid changes in the specific activity and concentration of glucose do not occur uniformly within the entire glucose pool. To compensate for this non-uniform mixing, a term of the nonsteady-state equation was multiplied by a correction factor (pool fraction) of $0.65[18,19]$. A sliding fit technique employing three consecutive values of glucose concentration and specific activity was also used in the calculations as described previously [20]. This approach for calculating non-steady-state kinetics of glucose turnover has been validated and confirmed in vivo [19].

During glucose infusions the endogenous rate of glucose production was calculated by subtracting the rate of infusion of exogenous glucose from the tracer-determined total rate of glucose appearance. An integrated value of $\mathrm{Ra}$ during the glucose infusion was calculated 

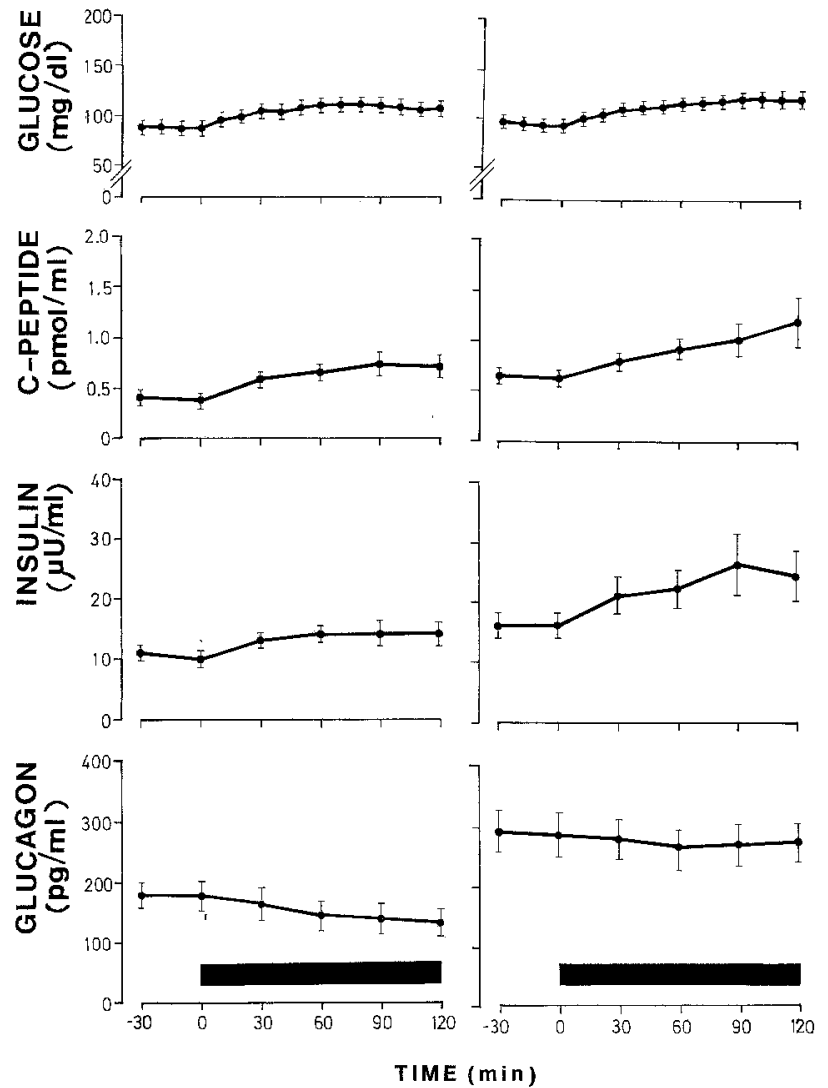

Fig. 1. Effect of glucose infusion (black bar) on plasma concentrations of glucose, C-peptide, insulin, and glucagon in eight control subjects (left) and in six patients with acromegaly (right). Data are shown as the mean \pm SEM

as the area under the Ra curve between 20 and $110 \mathrm{~min}$. This value was divided by 90 to obtain the average value during this $90 \mathrm{~min}$ period. In a similar way the average Ra during 90-110 min was calculated. Using the same technique the average $\mathrm{Rd}$ was obtained for both time periods during the glucose infusion. In addition, the metabolic clearance rate of glucose (MCR) was calculated as $R d / C$, where $C$ is the glucose concentration.

The activity of GC was determined as the difference in Ra measured with $2-{ }^{3} \mathrm{H}$-glucose and with $6{ }^{3} \mathrm{H}$-glucose in the basal state as well as between 20 and $110 \mathrm{~min}$ and between 90 and $110 \mathrm{~min}$ of the glucose infusion. In postabsorptive state the difference between $2 \cdot{ }^{3} \mathrm{H}$ glucose and $6-{ }^{3} \mathrm{H}$-glucose measures substrate cycling that corresponds the activity of glucokinase, the enzyme that catalyzes a reaction opposite to the net flux. During glucose infusion $2{ }^{3} \mathrm{H}$-glucose measures all endogenously released glucose, including glucose that recycles back, while $6{ }^{3} \mathrm{H}$-glucose measures endogenously released glucose that does not recycle back. Thus the difference between $2-{ }^{3} \mathrm{H}$ and $6-{ }^{3} \mathrm{H}$-glucose measures the rate at which endogenous glucose cycles back, but it does not measure the cycling that results from exogenous glucose infusion.

\section{Statistical analysis}

Results are expressed as the mean \pm SEM. Student's t-test was performed for paired and unpaired data after logarithmic transformation. Correlation analysis was undertaken using the Spearman rank correlation coefficient.

\section{Results}

In both control subjects and acromegalic patients an isotopic plateau was reached during the last $30 \mathrm{~min}$ of

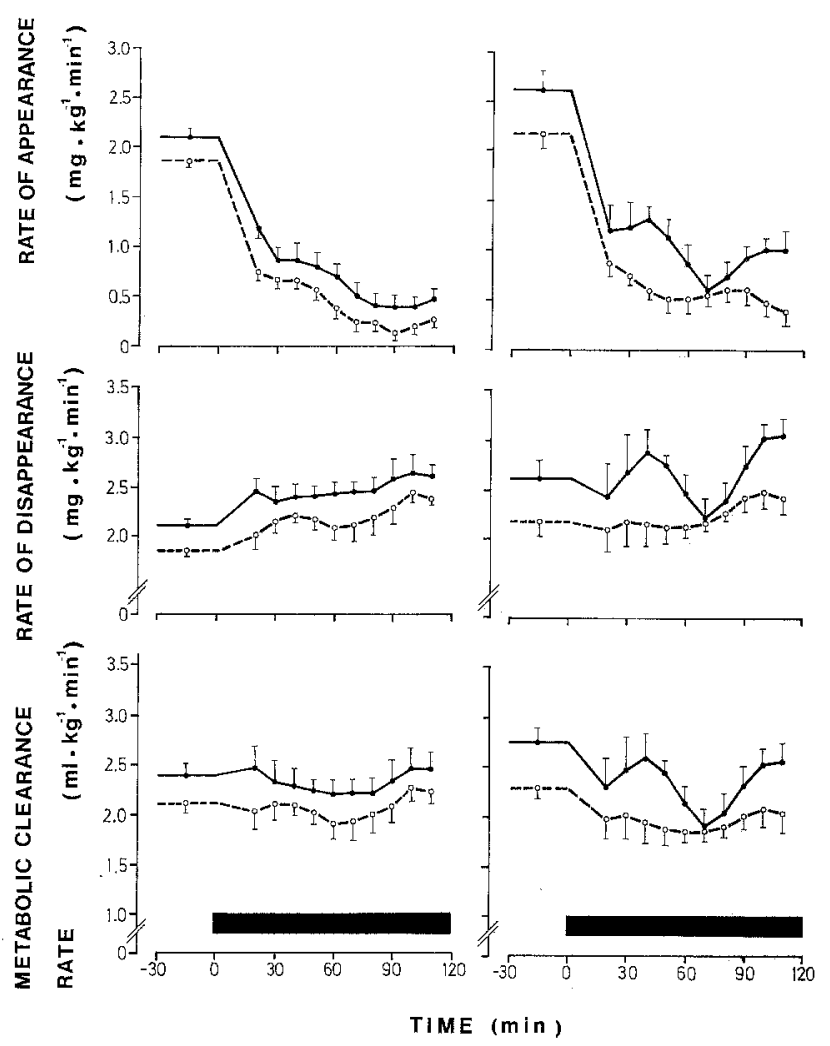

Fig. 2. Effect of glucose infusion (black bar) on rates of appearance $(\mathrm{Ra})$, disappearance $(\mathrm{Rd})$ and metabolic clearance (MCR) of glucose in eight control subjects (left) and in six patients with acromegaly (right). Data are shown as the mean $\pm S E M$, for $2{ }^{3} \mathrm{H}$-glucose $(-0)$ and for $6-{ }^{3} \mathrm{H}$-glucose $(\mathrm{O}----\mathrm{O})$

the equilibration period. The mean coefficient of variation (CV) was below 6\% for both isotopes. Plasma glucose was also stable during this period (Fig.1), with an average $\mathrm{CV}$ of $2.1 \%$ in the acromegalic patients and $0.6 \%$ in the control subjects. This implies that steady state conditions were obtained for labeled and unlabeled glucose by the end of the equilibration period.

Plasma glucose levels are shown in Figure 1. During the last $30 \mathrm{~min}$ of the equilibration period plasma glucose tended to be higher in the acromegalic patients than in the control subjects ( $95 \pm 3$ vs $89 \pm 3 \mathrm{mg} / \mathrm{dl}$, NS). During the glucose infusion, plasma glucose reached a plateau of about $120 \mathrm{mg} / \mathrm{dl}$ in the acromegalic patients and $110 \mathrm{mg} / \mathrm{dl}$ in the control subjects. Neither the plateau levels nor the incremental areas under the glucose curves were significantly different. Mean plasma Cpeptide was higher in acromegalic patients than in control subjects in the basal state $(0.64 \pm 0.03$ vs $0.40 \pm$ $0.05 \mathrm{pmol} / \mathrm{ml}, p<0.01$ ), whereas the plateau levels did not differ significantly $(1.11 \pm 0.20$ vs $0.73 \pm$ $0.10 \mathrm{pmol} / \mathrm{ml}, \mathrm{NS}$ ). Plasma insulin levels were higher in the acromegalic patients than in the control subjects in the basal state $(16 \pm 2$ vs $11 \pm 1 \mu \mathrm{U} / \mathrm{ml}, p<0.025)$ and at the end of the infusion period ( $25 \pm 4$ vs $14 \pm 2 \mu \mathrm{U} / \mathrm{ml}$, $p<0.025$ ). The increments of plasma C-peptide and insulin did not differ between the groups during the glucose infusion. Plasma glucagon concentrations were 
Table 2. Rate of appearance ( $\mathrm{Ra}$ ) of glucose in patients with acromegaly and in healthy controls. During the glucose infusion Ra was averaged during 20-110 min and during 90-110 min. Values are mean \pm SEM

\begin{tabular}{|c|c|c|c|c|}
\hline \multirow{3}{*}{$\begin{array}{l}\text { Experimental } \\
\text { condition }\end{array}$} & \multirow{3}{*}{$\begin{array}{l}\text { Tritium } \\
\text { label }\end{array}$} & \multicolumn{3}{|c|}{$\operatorname{Ra}\left(\mathrm{mg} \cdot \mathrm{kg}^{-1} \cdot \min ^{-1}\right)$} \\
\hline & & \multirow{2}{*}{$\begin{array}{l}\text { Healthy } \\
\text { controls }\end{array}$} & \multicolumn{2}{|c|}{ Acromegalic patients } \\
\hline & & & $\begin{array}{l}\text { Normal } \\
\text { glucose } \\
\text { tolerance }\end{array}$ & Diabetes \\
\hline \multirow[t]{2}{*}{ Basal state } & $6-{ }^{3} \mathrm{H}$-glucose & $\begin{array}{c}1.85 \pm 0.03 \\
* *\end{array}$ & $\begin{array}{c}2.18 \pm 0.15^{\mathrm{a}} \\
* *\end{array}$ & 4.85 \\
\hline & $2-{ }^{3} \mathrm{H}$-glucose & $2.10 \pm 0.07$ & $2.62 \pm 0.19^{a}$ & 5.95 \\
\hline \multirow[t]{2}{*}{$\begin{array}{l}\text { Glucose } \\
\text { infusion } \\
(20-110 \mathrm{~min})\end{array}$} & 6- ${ }^{3} \mathrm{H}$-glucose & $\begin{array}{c}0.40 \pm 0.04 \\
* * *\end{array}$ & $\begin{array}{c}0.58 \pm 0.07^{\mathrm{a}} \\
* *\end{array}$ & 2.33 \\
\hline & $2-{ }^{3} \mathrm{H}$-glucose & $0.64 \pm 0.08$ & $0.99 \pm 0.04^{\mathrm{b}}$ & 3.83 \\
\hline \multirow[t]{2}{*}{$\begin{array}{l}\text { Glucose } \\
\text { infusion } \\
(90-110 \mathrm{~min})\end{array}$} & $6-{ }^{3} \mathrm{H}$-glucose & $\begin{array}{c}0.20 \pm 0.04 \\
*\end{array}$ & $\begin{array}{c}0.49 \pm 0.12^{\mathrm{a}} \\
*\end{array}$ & 1.95 \\
\hline & $2 \cdot{ }^{3} \mathrm{H}$-glucose & $0.42 \pm 0.08$ & $0.98 \pm 0.09^{\mathrm{c}}$ & 4.20 \\
\hline
\end{tabular}

${ }^{\mathrm{a}} p<0.05,{ }^{\mathrm{b}} p<0.01$, and ${ }^{\mathrm{c}} p<0.001$ acromegalic patients vs control subjects

${ }^{*} p<0.05, * * p<0.01$, and $* * * p<0.0012-{ }^{3} \mathrm{H}$-glucose vs $6-{ }^{3} \mathrm{H}$-glucose

Table 3. Rate of disappearance (Rd) of glucose in patients with acromegaly and in healthy controls. During the glucose infusion Rd was averaged during $20-110 \mathrm{~min}$ and during $90-110 \mathrm{~min}$. Values are mean $\pm S E M$

\begin{tabular}{|c|c|c|c|c|}
\hline \multirow{3}{*}{$\begin{array}{l}\text { Experimental } \\
\text { condition }\end{array}$} & \multirow{3}{*}{$\begin{array}{l}\text { Tritium } \\
\text { label }\end{array}$} & \multicolumn{3}{|c|}{$\mathrm{Ra}\left(\mathrm{mg} \cdot \mathrm{kg}^{-1} \cdot \mathrm{min}^{-1}\right)$} \\
\hline & & \multirow{2}{*}{$\begin{array}{l}\text { Healthy } \\
\text { controls }\end{array}$} & \multicolumn{2}{|c|}{ Acromegalic patients } \\
\hline & & & $\begin{array}{l}\text { Normal } \\
\text { glucose } \\
\text { tolerance }\end{array}$ & Diabetes \\
\hline \multirow[t]{2}{*}{ Basal state } & 6- -3 -glucose & $\begin{array}{c}1.85 \pm 0.03 \\
* *\end{array}$ & $\begin{array}{c}2.18 \pm 0.15^{\mathrm{a}} \\
* *\end{array}$ & 4.85 \\
\hline & $2-{ }^{3} \mathrm{H}$-glucose & $2.10 \pm 0.07$ & $2.62 \pm 0.19^{\mathrm{a}}$ & 5.95 \\
\hline \multirow[t]{2}{*}{$\begin{array}{l}\text { Glucose } \\
\text { infusion } \\
(20-110 \mathrm{~min})\end{array}$} & $6-{ }^{3} \mathrm{H}$-glucose & $\begin{array}{c}2.20 \pm 0.08 \\
* *\end{array}$ & $\begin{array}{l}2.25 \pm 0.12 \\
* * * *\end{array}$ & 4.35 \\
\hline & $2-{ }^{3} \mathrm{H}$-glucose & $2.47 \pm 0.09$ & $2.67 \pm 0.14$ & 5.93 \\
\hline \multirow[t]{2}{*}{$\begin{array}{l}\text { Glucose } \\
\text { infusion } \\
(90-110 \mathrm{~min})\end{array}$} & 6- ${ }^{3} \mathrm{H}-$ glucose & $\begin{array}{c}2.37 \pm 0.10 \\
*\end{array}$ & $\begin{array}{l}2.45 \pm 0.15 \\
\quad * *\end{array}$ & 4.10 \\
\hline & $2{ }^{3} \mathrm{H}$-glucose & $2.61 \pm 0.16$ & $2.95 \pm 0.12$ & 6.28 \\
\hline
\end{tabular}

${ }^{a} p<0.05$ acromegalic patients vs control subjects

${ }^{*} p<0.05,{ }^{* *} p<0.01$, and ${ }^{* * *} p<0.0012-{ }^{3} \mathrm{H}$-glucose vs $6-{ }^{3} \mathrm{H}$-glucose

higher in acromegalic patients than in control subjects in the basal state and at the end of the glucose infusion $(p<0.025)$. Within both groups hyperglycaemia resulted in decreased glucagon concentrations $(p<0.05)$. In acromegalic patients basal plasma $\mathrm{GH}$ averaged $47 \pm$ $24 \mathrm{ng} / \mathrm{ml}$. There was a slight but not significant increase in $\mathrm{GH}$ during the glucose infusion. The correlation between basal levels of GH and glucagon was not significant $(r=0.829)$.

As summarized in Table 2 and Figure 2, Ra measured after an overnight fast was significantly higher in the acromegalic patients than in the control subjects with both isotopes. The basal Ra determined with $6-{ }^{3} \mathrm{H}-$ glucose was lower than with $2-{ }^{3} \mathrm{H}$-glucose in acromegalic patients and control subjects. The glucose infusion caused a prompt suppression of $\mathrm{Ra}$ irrespective of the isotope used. During the last $20 \mathrm{~min}$ of glucose infusion the suppression of $\mathrm{Ra}$ was less pronounced in the acromegalic patients than in the control subjects with $6{ }^{3} \mathrm{H}$-glucose $(77 \pm 6 \%$ vs $90 \pm 2 \%, p<0.05)$ and with $2-{ }^{3} \mathrm{H}$-glucose $(62 \pm 4 \%$ vs $81 \pm 4 \%, p<0.005)$. Thus, also during glucose infusion (Table 2) Ra remained higher in the acromegalic patients than in the control subjects.

$\mathrm{Rd}$ was by definition identical to $\mathrm{Ra}$ in the basal state (Table 3 and Fig.2). During the glucose infusion there was no significant change in $\mathrm{Rd}$ in the acromegalic patients. In controls, however, Rd determined with $6-{ }^{3} \mathrm{H}$-glucose and with $2{ }^{3} \mathrm{H}$-glucose increased significantly $(p<0.005)$.

The basal MCR tended to be higher in the acromegalic patients than in the control subjects but the difference was not significant (Table 4 and Fig. 2). The glucose infusion decreased MCR in acromegalic patients with both $6-{ }^{3} \mathrm{H}$-glucose $(p<0.01)$ and with $2-{ }^{3} \mathrm{H}$-glucose $(p<0.005)$ while MCR did not change in control subjects.

In the basal state a significant amount of glucose was metabolized through GC in acromegalic patients and control subjects (Table $5, p<0.05$ ). The cycling of endogenous glucose remained unchanged during the glucose infusion. Interestingly, the basal GC activity as well as cycling of endogenous glucose during glucose infusion were higher in acromegalic patients than in control subjects $(p<0.05)$. In the acromegalic patients there was a correlation between basal GH and GC $(r=0.943, p<0.05)$, while basal glucagon levels were not significantly related to $\mathrm{GC}(r=0.800)$.

The acromegalic patient with manifest diabetes (BA) had a basal plasma glucose level of $198 \mathrm{mg} / \mathrm{dl}$, which did not change during the glucose infusion. Plasma C-peptide was $1.8 \mathrm{pmol} / \mathrm{ml}$ throughout the experiment while plasma insulin levels increased from 35 to $45 \mu \mathrm{U} / \mathrm{ml}$. Basal Ra was about twice that of acromegalic patients with normal glucose tolerance. During the glucose infusion the degree of suppression of $\mathrm{Ra}$ was similar to that found in the nondiabetic acromegalic group. The activity of basal GC as well as the endogenous glucose cycling measured during glucose infusion were considerably increased and amounted to 1.10 and $1.50 \mathrm{mg} \cdot \mathrm{kg}^{-1} \cdot \mathrm{min}^{-1}$, respectively.

\section{Discussion}

In order to characterize defects which can lead to glucose intolerance in acromegaly we investigated glucose turnover, and in particular glucose cycling, in patients with normal glucose tolerance. Once diabetes is established it is difficult to dissociate metabolic defects due to GH hypersecretion from the effects of hyperglycaem- 
Table 4. Metabolic clearance rate (MCR) of glucose in patients with acromegaly and in healthy controls. During the glucose infusion MCR was averaged during $20-110 \mathrm{~min}$ and during 90-110 min. Values are mean $\pm S E M$

\begin{tabular}{|c|c|c|c|c|}
\hline \multirow{3}{*}{$\begin{array}{l}\text { Experimental } \\
\text { condition }\end{array}$} & \multirow{3}{*}{$\begin{array}{l}\text { Tritium } \\
\text { label }\end{array}$} & \multicolumn{3}{|c|}{$\operatorname{MCR}\left(\mathrm{ml} \cdot \mathrm{kg}^{-1} \cdot \mathrm{min}^{-1}\right)$} \\
\hline & & \multirow{2}{*}{$\begin{array}{l}\text { Healthy } \\
\text { controls }\end{array}$} & \multicolumn{2}{|c|}{ Acromegalic patients } \\
\hline & & & $\begin{array}{l}\text { Normal } \\
\text { glucose } \\
\text { tolerance }\end{array}$ & Diabetes \\
\hline \multirow[t]{2}{*}{ Basal state } & $6-{ }^{3} \mathrm{H}$-glucose & $\begin{array}{c}2.11 \pm 0.09 \\
* *\end{array}$ & $\begin{array}{c}2.30 \pm 0.11 \\
* * *\end{array}$ & 2.46 \\
\hline & $2{ }^{3} \mathrm{H}$-glucose & $2.39 \pm 0.12$ & $2.76 \pm 0.13$ & 3.02 \\
\hline \multirow[t]{2}{*}{$\begin{array}{l}\text { Glucose } \\
\text { infusion } \\
(20-110 \mathrm{~min})\end{array}$} & $6-{ }^{3} \mathrm{H}$-glucose & $\begin{array}{c}2.06 \pm 0.13 \\
* *\end{array}$ & $\begin{array}{c}1.96 \pm 0.15 \\
* * *\end{array}$ & 2.17 \\
\hline & $2-{ }^{3} \mathrm{H}$-glucose & $2.31 \pm 0.14$ & $2.33 \pm 0.17$ & 2.96 \\
\hline \multirow[t]{2}{*}{$\begin{array}{l}\text { Glucose } \\
\text { infusion } \\
(90-110 \mathrm{~min})\end{array}$} & $6-{ }^{3} \mathrm{H}$-glucose & $\begin{array}{c}2.18 \pm 0.13 \\
*\end{array}$ & $\begin{array}{c}2.05 \pm 0.17 \\
* *\end{array}$ & 2.08 \\
\hline & $2{ }^{3} \mathrm{H}$-glucose & $2.40 \pm 0.19$ & $2.46 \pm 0.17$ & 3.19 \\
\hline
\end{tabular}

$* p<0.05, * * p<0.01$, and $* * * p<0.0012{ }^{3} \mathrm{H}$-glucose vs $6-^{3} \mathrm{H}$-glucose

Table 5. Activity of glucose cycling $(\mathrm{GC})$ in patients with acromegaly and in healthy controls. During the glucose infusion $\mathrm{GC}$ was calculated during 20-110 min and during 90-110 min. Values are mean \pm SEM

\begin{tabular}{|c|c|c|c|}
\hline \multirow[t]{3}{*}{ Experimental condition } & \multicolumn{3}{|c|}{$\mathrm{GC}\left(\mathrm{mg} \cdot \mathrm{kg}^{-1} \cdot \mathrm{min}^{-1}\right)$} \\
\hline & \multirow{2}{*}{$\begin{array}{l}\text { Healthy } \\
\text { controls }\end{array}$} & \multicolumn{2}{|c|}{ Acromegalic patients } \\
\hline & & $\begin{array}{l}\text { Normal } \\
\text { glucose } \\
\text { tolerance }\end{array}$ & Diabetes \\
\hline Basal state & $0.25 \pm 0.07$ & $0.44 \pm 0.08^{\mathrm{a}}$ & 1.10 \\
\hline Glucose infusion (20-110 $\mathrm{min})$ & $0.24 \pm 0.05$ & $0.41 \pm 0.05^{\mathrm{a}}$ & 1.50 \\
\hline Glucose infusion (90-110 $\mathrm{min}$ ) & $0.22 \pm 0.09$ & $0.49 \pm 0.11$ & 2.25 \\
\hline
\end{tabular}

${ }^{a} p<0.05$ acromegalic patients vs control subjects

ia and other metabolic derangements which accompany it. After an overnight fast in acromegalic patients Ra was significantly elevated despite hyperinsulinaemia, while MCR was normal. During glucose infusion, Ra was not suppressed as effectively in the acromegalic patients as in control subjects although the prevailing insulin levels were higher. Moreover, in the acromegalic patients glucose administration did not augment glucose uptake, resulting in a decreased MCR.

Our findings resemble, in several respects, those seen during short-term administration of $\mathrm{GH}$ to healthy human volunteers [21, 22]. A $12 \mathrm{~h}$ infusion of $\mathrm{GH}$, which gave rise to increments of plasma GH within the physiological range, decreased both insulin-mediated suppression of $\mathrm{Ra}$ and the stimulatory effect of insulin on $\mathrm{Rd}$. In these studies, however, basal Ra was not increased. In contrast, when pharmacological doses of GH were infused into normal dogs over a 3-8 day period, not only were the $\mathrm{Ra}$ and $\mathrm{Rd}$ response to insulin altered but there was also a clear increase in basal $\mathrm{Ra}[23$, 24].
A novel finding in the present study is that acromegaly augmented the activity of GC. This means that a large amount of glucose that has been taken up by the liver and phosphorylated is promptly dephosphorylated and released to the blood stream instead of being polymerized to glycogen or oxidized. We have determined GC by subtracting glucose turnover measured with $6-{ }^{3} \mathrm{H}$-glucose from that measured using $2-{ }^{3} \mathrm{H}$-glucose. This technique is based on two assumptions: 1) $6-{ }^{3} \mathrm{H}-$ glucose provides a true measure of hepatic glucose production, and 2) there are no isotope effects. With respect to the first assumption, tritium from $6-{ }^{3} \mathrm{H}$-glucose is retained through the whole glycolytic process [25] and is lost to a large extent by carboxylation-decarboxylation reactions between pyruvate and dicarboxylic acids as well as by the action of glutamate-pyruvate transaminase. The measurement of hepatic glucose production with $6{ }^{3} \mathrm{H}$-glucose is thus not influenced by activity of the Cori cycle and reflects the true rate of hepatic glucose production in vivo $[26,27]$ and in vitro [28]. The second assumption implies that tritium loss from $2-{ }^{3} \mathrm{H}-$ glucose is representative of hydrogen loss in the hexose isomerase reaction. This, however, has not been completely ascertained. The possibility that there is an isotope effect cannot be fully excluded [28]. Such an effect could result in retention of tritium in position 2 of glucose 6-phosphate, leading to underestimation of glucose cycle activity.

All four disturbances of glucose metabolism appearing in our acromegalic patients with normal OGTT (increased basal $\mathrm{Ra}$, impaired action of insulin on $\mathrm{Ra}$ and $\mathrm{Rd}$, and increased GC) are also characteristic features of patients with Type 2 diabetes [29-31]. In the latter patients, however, these defects are more pronounced and in addition the B cell capacity to release insulin is impaired (for review see 32), leading to overt hyperglycaemia.

Interestingly, in our patient who had both acromegaly and Type 2 diabetes, basal $\mathrm{Ra}$ and GC were as high as 4.85 and $1.10 \mathrm{mg} \cdot \mathrm{kg}^{-1} \cdot \mathrm{min}^{-1}$, respectively. This single experiment cannot constitute the basis for major conclusions and has to be extended to include more patients with acromegaly and diabetes.

In acromegaly basal GC activity was correlated with plasma GH levels, suggesting that the hormone may be directly involved in regulation of this metabolic pathway. Since glucagon is known to increase the activity of glucose 6-phosphatase [33] and the activity of GC [27], it is possible that hyperglucagonaemia found in our acromegalic patients at least partially contributes to increased GC. Similar to glucagon, other hormones known to augment GC activity, such as cortisone and thyroid hormone, have also been shown to increase the activity of glucose 6-phosphatase [33]. The interaction between $\mathrm{GH}$ and this enzyme has not been studied.

The cellular mechanisms behind the effects of GH on carbohydrate metabolism in liver and extrahepatic tissues are not clear. Several experimental studies have suggested that a short-term GH excess has no or little 
effect on the binding of insulin to its receptor [21, 22]. In monocytes from acromegalic patients with normal OGTT the number of insulin binding sites is reduced only in patients with plasma $\mathrm{GH}$ levels $>30 \mathrm{ng} / \mathrm{ml}[9]$. Hence, the GH-induced insulin resistance may involve post-receptor events to a large extent.

In conclusion, it appears that in acromegalic patients defects in glucose metabolism can be detected with sensitive tracer methods, even when fasting plasma glucose is near normal and when OGTT is not impaired. Interestingly the major defect in the postabsorptive state was a $70 \%$ increase in glucose cycling, while the increment in glucose production was much less pronounced (17\%).

Acknowledgements. We are grateful to Mr A Roovete, Ms K Waldelöf and Ms E Sandberg for excellent technical assistance. This work was supported by the Swedish Medical Research Council (grant no.0034), the Nordic Insulin Foundation (Gentofte, Denmark), and the Swedish Diabetes Association.

\section{References}

1. Daughaday WH (1985) The adenohypophysis. In: Wilson JD, Foster DW (eds) Textbook of endocrinology. WB Saunders Company, Philadelphia London Toronto, p 605

2. Beck P, Schalch DS, Parker ML, Kipnis DM, Daughaday WH (1965) Correlative studies of growth hormone and insulin plasma concentrations with metabolic abnormalities in acromegaly. J Lab Clin Med 66: 366-379

3. Sönksen PH, Greenwood FC, Ellis JP, Lowy C, Rutherford A, Nabarro JDN (1967) Changes of carbohydrate tolerance in acromegaly with progress of the disease and in response to treatment. J Clin Endocrinol Metab 27: 1418-1430

4. Fineberg SE, Merimee TJ, Rabinowitz D, Edgar PJ (1970) Insulin secretion in acromegaly. J Clin Endocrinol Metab 30: 288-292

5. Trimble ER, Atkinson AB, Buchanan KD, Hadden DR (1980) Plasma glucagon and insulin concentrations in acromegaly. J Clin Endocrinol Metab 51: 626-631

6. Galbraith HJB, Ginsburg J, Paton A (1960) Decreased response to intra-arterial insulin in acromegaly. Diabetes $9: 459-465$

7. Feek CM, Bevan JS, Taylor S, Brown NS, Baird JD (1981) The effect of bromocriptine on insulin secretion and glucose tolerance in patients with acromegaly. Clin Endocrinol 15:473-478

8. Eastman RC, Gorden P, Roth J (1979) Conventional supervoltage irradiation is an effective treatment for acromegaly. J Clin Endocrinol Metab 48: 931-940

9. Muggeo M, Bar RS, Roth J, Kahn CR, Gorden P (1979) The insulin resistance of acromegaly: Evidence for two alterations in the insulin receptor on circulating monocytes. J Clin Endocrinol Metab $48: 17-25$

10. Liuzzi A, Chiodini PG, Botalla L, Cremascoli G, Siverstrini F (1972) Inhibitory effect of L-dopa on GH release in acromegalic patients. J Clin Endocrinol Metab 35: 941-943

11. Irie M, Tsushima T(1972) Increase of serum growth hormone concentration following thyrotropin-releasing hormone injection in patients with acromegaly or gigantism. J Clin Endocrinol Metab 35: $97-100$

12. Efendić S, Wajngot A, Cerasi E, Luft R (1980) Insulin release, insulin sensitivity, and glucose intolerance. Proc Natl Acad Sci USA 77: 7425-7429

13. Hugget ASG, Nixon DA (1957) Use of glucose oxidase, peroxidase and $\mathrm{O}$-dianisidine in determination of blood and urinary glucose. Lancet $2: 368-370$
14. Herbert V, Lau KS, Gottlieb CW, Bleicher SJ (1965) Coated charcoal immunoassay of insulin. J Clin Endocrinol Metab 25: 1375-1384

15. Faloona GR, Unger RH (1974) Glucagon radioimmunoassay. In: Jaffe BM, Behrman HR (eds) Methods of radioimmunoassay. Academic Press, New York, pp 317-330

16. Dunn DF, Friedman B, Maass AR, Reichard GA, Weinhouse $S$ (1957) Effectos of insulin on blood glucose entry and removal rates in normal dogs. J Biol Chem 225:225-237

17. DeBodo RC, Steele R, Altszuler N, Dunn A, Bishop JS (1963) On the hormonal regulation of carbohydrate metabolism; studies with ${ }^{14} \mathrm{C}$ glucose. Recent Prog Horm Res 19: 445-488

18. Cowan HS, Hetenyi, Jr G (1971) Glucoregulatory responses in normal and diabetic dogs recorded by a new tracer method. Metabolism 20: 360-372

19. Radziuk J, Norwich KH, Vranić M (1978) Experimental validation of measurements of glucose turnover in nonsteady state. Am J Physiol 234 (Endocrinol Metab Gastrointest Physiol 3): E84-E93

20. Cherrington AD, Vranić M (1973) Effect on arginine on glucose turnover and plasma free fatty acids in normal dogs. Diabetes 22 : $537-543$

21. Bratusch-Marrain PR, Smith D, DeFronzo RA (1982) The effect of growth hormone on glucose metabolism and insulin secretion in man. J Clin Endocrinol Metab 55: 973-982

22. Rizza RA, Mandarino LJ, Gerich JE (1982) Effects of growth hormone on insulin action in man. Mechanisms of insulin resistance, impaired suppression of glucose production, and impaired stimulation of glucose utilization. Diabetes 31:663-669

23. Bishop JS, Steele R, Altszuler N, Rathgeb I, Bjerknes C, DeBodo RC (1967) Diminished responsiveness to insulin in the growth hormone-treated normal dog. Am J Physiol 212: 272-278

24. Altszuler N, Rathgeb I, Winkler B, DeBodo RC, Steele R (1968) The effects of growth hormone on carbohydrate and lipid metabolism in the dog. Ann N Y Acad Sci 148: 441-458

25 . Hue $\mathrm{L}$ (1981) The role of futile cycles in the regulation of carbohydrate metabolism in the liver. In: Meister A (ed) Advances in enzymology. John Wiley, New York, pp 247-331

26. Dunn A, Chenoweth M, Schaeffer LD (1967) Estimation of glucose turnover and the Cori cycle using glucose $6-\mathrm{t}-{ }^{14} \mathrm{C}$. Biochemistry $6: 6-11$

27. Issekutz Jr B (1977) Studies on hepatic glucose cycles in normal and methylprednisolone-treated dogs. Metabolism 26:157-170

28. Katz J, Rognstad R (1976) Futile cycles in the metabolism of glucose. Curr Top Cell Regul 10:237-289

29. DeFronzo RA, Gunnarsson R, Björkman O, Olsson M, Wahren J (1985) Effects of insulin on peripheral and splanchnic glucose metabolism in noninsulin-dependent (Type II) diabetes mellitus. J Clin Invest 76: 149-155

30. Kolterman OG, Gray RS, Griffin J, Burstein P, Insel J, Scarlett JA, Olefsky JM (1981) Receptor and postreceptor defects contribute to the insulin resistance in noninsulin-dependent diabetes mellitus. J Clin Invest 68: 957-969

31. Efendic S, Wajngot A, Vranic M (1985) Increased activity of the glucose cycle in the liver: Early characteristic of type 2 diabetes. Proc Natl Acad Sci 82: 2965-2969

32. Efendic S, Luft R, Wajngot A (1984) Aspects of the pathogenesis of type 2 diabetes. Endocrine Rev 5: 395-410

33. Speth M, Schulze HU (1981) Hormone-induced effects on the rat liver microsomal glucose-6-phosphatase system in vitro. Biochem Biophys Res Commun 99: 134-141

Received: 1 April 1986

and in revised form: 10 September 1986

Professor Suad Efendić

Department of Endocrinology

Karolinska Hospital

S-104 01 Stockholm

Sweden 